\title{
Effects of thermized donkey milk with lysozyme activity on altered gut barrier in mice exposed to water-avoidance stress
}

\author{
Sophie Yvon, ${ }^{1}$ Lauriane Schwebel, ${ }^{1}$ Loubnah Belahcen, ${ }^{2}$ Helene Tormo, ${ }^{2}$ Magali Peter, ${ }^{2}$ \\ Djamila Ali Haimoud-Lekhal, ${ }^{3}$ Hélène Eutamene, ${ }^{1 *} \dagger$ and Gwenaelle Jard ${ }^{2 *}$ \\ ${ }^{1}$ Unité Mixte de Recherche 1331 Toxalim, Institut National de la Recherche Agronomique, Institut National Polytechnique-Ecole Nationale \\ Vétérinaire de Toulouse, Institut National Polytechnique-Purpan, Université de Toulouse, Neuro-Gastroenterology and Nutrition Group, Toulouse, \\ France \\ ${ }^{2}$ Equipe Agromolécules et Agroalimentaire, Université de Toulouse, Institut National Polytechnique-Purpan, Toulouse, France \\ ${ }^{3}$ Unité Mixte de Recherche 1388 Génétique, Physiologie et Systèmes d'Elevage, Institut National de la Recherche Agronomique, \\ Institut National Polytechnique-Purpan, Toulouse, France
}

\section{ABSTRACT}

Nutrition plays a crucial role in human gut health through the improvement of gut barrier functionality. Donkey milk represents an interesting source of natural antimicrobial factors such as lysozyme. Recently, anti-inflammatory properties of donkey milk lysozyme activity were described in a mouse model of ileitis. The current increase of donkey milk consumption highlights the necessity to propose a healthy milk compliant with microbiological standards. This study aims to define a heat treatment of donkey milk, retaining its high lysozyme activity, and to evaluate its beneficial effects on a gut barrier impairment model due to chronic stress in mice. To perform this experiment, samples of raw donkey milk were collected in 15 distinct French farms. Microbiological analysis and lysozyme content and activity were evaluated for each sample. Then, several heat treatments were carried out to define a time and temperature combination that allowed for both a reduction in the number of total micro-organisms, increasing the shelf-life of the product, and preservation of lysozyme activity. The beneficial effect of heated donkey milk on the gut barrier of mice was evaluated and compared with raw donkey milk. We found that samples of raw donkey milk showed low total mesophilic microbial counts, and no pathogens were detected. Among the different heat-treatment procedures tested, a 2-min, $72^{\circ} \mathrm{C}$ combination was determined to be the most optimal time and temperature combination to preserve lysozyme activity and increase the shelf-life of donkey milk. Oral administration of this heat-treated donkey

Received March 18, 2019.

Accepted May 16, 2019.

*These authors contributed equally to this work.

†Corresponding author: helene.eutamene@inra.fr milk in mice counteracted chronic stress-induced intestinal damage, illustrated by gut hyper-permeability and low-grade inflammation, similar to raw donkey milk. We have demonstrated for the first time that oral intervention with donkey milk, optimally heat-treated to retain enzymatic lysozyme activity, improves intestinal barrier damage linked to psychological stress in mice. Key words: donkey milk, lysozyme activity, gut, pasteurization

\section{INTRODUCTION}

Donkey milk (DKM) represents a significant source of natural protective antimicrobial factors (Šarić et al., 2012; Cosentino et al., 2015a, 2016; Labella et al., 2016). It has been shown that DKM has ability to improve human health (Brumini et al., 2015; Aspri et al., 2017). For example, DKM can be useful in cases of cow milk allergy (Carroccio et al., 2000), in the prevention of atherosclerosis (Tafaro et al., 2007), and in the positive stimulation of the immune system (Jirillo et al., 2010). All these relevant healthy effects seem to be related to the biochemical composition of DKM. Whey proteins represent 35 to $50 \%$ of its nitrogen fraction, with $2 \mathrm{~g} / \mathrm{L}$ of lactoferrin and 1 to $4 \mathrm{~g} / \mathrm{L}$ of lysozyme (Guo et al., 2007). The fraction of DKM containing lysozyme exerts anti-tumoral activities in vitro (Mao et al., 2009). Recently, we showed that daily DKM consumption with constant lysozyme activity (LZA) has anti-inflammatory effects in a mouse model of ileitis. This effect is highly dependent on LZA and is associated with normalization of antimicrobial peptide levels in Paneth cells. These data suggest that DKM must contain high LZA in order to obtain beneficial effects on gut mucosa (Yvon et al., 2016).

Nutrition plays a crucial role in human gut health through its effects on gut microbiota and barrier func- 
tionality (Gottlieb et al., 2017; Marco et al., 2017). Homeostasis is bound to the interactions of commensal bacteria and host immunity. A disruption of this homeostasis is found in several pathologies, such as inflammatory bowel disease (IBD) or irritable bowel syndrome (IBS; Ma et al., 2018). Low-grade intestinal mucosal inflammation is described in IBS patients and associated with increase in gut permeability and visceral pain (Zhou et al., 2009; Vivinus-Nébot et al., 2013). In humans, stressful life events exacerbate these gut disorders (Lerebours et al., 2007; Moloney et al., 2016). In mice, chronic stress, such as water-avoidance stress (WAS), induces disruption of the colonic epithelial barrier, promotes gut micro-inflammation, induces hypersensitivity to colorectal distension, and creates dysbiosis (Bradesi, 2005; Ferrier et al., 2006; Larauche et al., 2011; Watanabe et al., 2016).

The presence of antimicrobial components such as lysozyme, immunoglobulins, and lactoferrin in raw DKM keeps total levels of bacteria low (Pilla et al., 2010; Cavallarin et al., 2015; Aspri et al., 2017), and therefore confers a long natural shelf life (Zhang et al., 2008). Processed in other foodstuffs, DKM acts to prevent bacterial growth and effectively extends their shelf life (Cosentino et al., 2015b). However, contamination with Enterococcus faecium and Enterococcus faecalis, strains that are pathogenic in humans, has been detected in raw DKM (Verraes et al., 2014; Aspri et al., 2016). Responsible for an estimated $80 \%$ of Enterococcus infections (Kayser, 2003), E. faecalis is a strain adaptable to different substrates and resistant to both pasteurization (30 min at $62^{\circ} \mathrm{C}$; Kearns et al., 1995) and antimicrobial LZA (Hébert et al., 2007). The recent expansion of donkey breeding and the increased consumption of DKM sold on farms for direct consumption highlight the necessity for farmers to offer a safe and biologically effective DKM to consumers. Heat treatments with appropriate time and temperature combinations are used in the production of milk to obtain a safe and suitable end product. A heat treatment of $30 \mathrm{~min}$ at $62.5^{\circ} \mathrm{C}$ is currently applied to human breast milk (Sousa et al., 2014; van der Voorn et al., 2017). However, this time and temperature combination causes a drastic loss of up to $44 \%$ of LZA (Sousa et al., 2014).

This study aimed (1) to establish an overview of lysozyme levels and activity in microbiologically characterized French DKM; (2) to develop a low-cost heattreatment process to render DKM compliant with microbiological standards and preserve its LZA; and (3) to test the ability of this heated milk, compared with raw DKM, to counteract the gut hyper-permeability and micro-inflammation induced by chronic stress in mice.

\section{MATERIALS AND METHODS}

\section{Experimental Design}

This study comprised 3 consecutive phases, diagrammed in Figure 1. The first consisted of a diagnosis phase to describe the bacterial load and the lysozyme levels and activity in 15 raw DKM samples collected from 15 different French farms. The next phase consisted of optimizing the thermization process on 1 selected milk, obtained from La Ferme du Hitton (Biran, France), chosen for the farm's high quality of rearing and animal well-being. First, several heat treatments were carried out to define a time and temperature combination that would both reduce the number of total microorganisms and preserve LZA in DKM (step 1). Second, linked to the low level of microorganisms contained in the selected DKM, an enrichment with endogenous bacteria and an artificial contamination with the thermotolerant strain E. faecalis were performed (step 2). Then, the best thermization treatment process for generating safe milk, compliant with microbiological standards, was selected from the suitable heat treatments previously tested (step 3). On this basis, an aging test was performed to characterize the shelf life of the thermized DKM (step 4). In the last phase of the study, the beneficial effects of pasteurized DKM were evaluated in an in vivo model of chronic stress in mice, which promotes gut hyper-permeability and a microinflammation response.

\section{Donkey Milk Sample Collection}

Donkey milk samples were provided from 15 different farms across France. After milking, the samples were collected in sterile flasks, immediately frozen, transported to the laboratory under frozen conditions, and stored at $-18^{\circ} \mathrm{C}$ until analysis.

\section{Microbiological Analysis}

Microbiological Load. Total mesophilic bacteria, lactic acid bacteria, and thermotolerant coliforms were counted to evaluate the health quality of the different raw DKM coming from the 15 French farms. One milliliter each of undiluted samples and dilutions of $10^{-1}$, $10^{-2}$, and $10^{-3}$ of each sample were used for counting. All these analyses were performed in triplicate. The media and the incubation conditions are described in Table 1. Tests for pathogens (Listeria monocytogenes, Salmonella spp., Escherichia coli, and coagulase-positive Staphylococcus) were conducted in all the samples by Socsa Analyse (L'Union, France). The results were expressed in $\log _{10} \mathrm{cfu} / \mathrm{mL}$. 


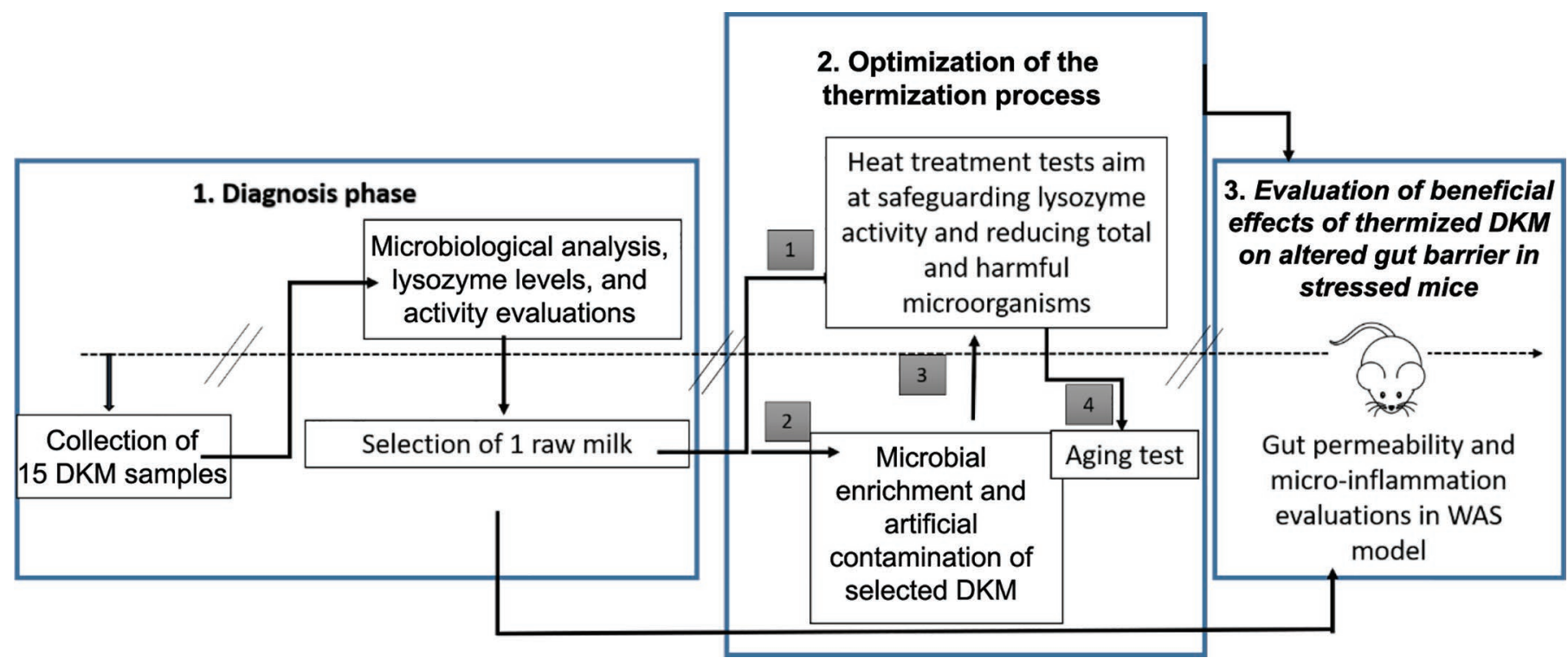

Figure 1. Experimental design of the study. (1) Diagnosis phase; evaluation of the health quality of raw donkey milk (DKM) from 15 French farms. (2) Optimization of a thermization process to preserve lysozyme activity and reduce harmful microorganisms. (3) Evaluation of beneficial effects of thermized DKM on altered gut barrier in mice exposed to water-avoidance stress (WAS).

Microbial Enrichment and Artificial Contamination of Selected DKM. Linked to the low level of microorganisms counted in the selected DKM from La Ferme du Hitton, an enrichment of endogenous bacteria and an artificial contamination with $E$. faecalis were performed. Briefly, a bacterial smear from donkey milk growth on PCA medium was enriched in a brainheart medium incubated overnight at $37^{\circ} \mathrm{C}$, and several aliquots were stored at $-20^{\circ} \mathrm{C}$ with cryoprotectant. Then, DKM was enriched to reach $6.3 \log _{10} \mathrm{cfu} / \mathrm{mL}$ of total bacteria in milk. Artificial contamination was performed by adding $7.3 \log _{10} \mathrm{cfu} / \mathrm{mL}$ E. faecalis strain (EI-Purpan collection, Toulouse, France) to DKM. Using the different media described in Table 1, total bacteria and E. faecalis bacteria were counted before and after the heat treatments tested that did not alter the enzymatic LZA.
Aging Tests of Pasteurized DKM. An aging test of the selected pasteurized DKM $\left(2 \min / 72^{\circ} \mathrm{C}\right)$ was performed at Lanagram Laboratories (Mazamet, France). The health and safety criteria were determined in $100 \mathrm{~g}$ of DKM samples obtained at $1,7,10,15$, and $20 \mathrm{~d}$ post-heat treatment. More precisely, counts (cfu) from total microorganisms (NF EN ISO 4833-1), enterobacteria (NF V 08-054), B-glucuronidase-positive Escherichia coli (NF ISO 16649-2), coagulase-positive staphylococci (NF EN ISO 6888-2), and the presence or absence of Salmonella spp. (AES 10/11-07/11) and L. monocytogenes (BKR 23/2-11/02) were monitored.

\section{Lysozyme Levels and Activity}

Concentration of Lysozyme. Levels of lysozyme were determined using the reversed-phase (RP)-HPLC

Table 1. Methods used in microbiological analysis to evaluate the health quality of raw donkey milks selected from 15 French farms

\begin{tabular}{|c|c|c|c|}
\hline Groups of microorganisms & Medium & $\begin{array}{l}\text { Incubation } \\
\text { conditions }\end{array}$ & $\begin{array}{l}\text { Inoculation } \\
\text { method }\end{array}$ \\
\hline Total bacterial count (TBC) & Plate count agar $(\mathrm{PCA})+0.1 \%$ skim milk powder $\left(\right.$ Biokar $\left.^{1}\right)$ & $30^{\circ} \mathrm{C}, 72 \mathrm{~h}$ & Inclusion $(1 \mathrm{~mL})$ \\
\hline Thermotolerant coliforms & Violet red bile lactose (Biokar) & $44^{\circ} \mathrm{C}, 48 \mathrm{~h}$ & Inclusion (1 mL) \\
\hline Lactic acid bacteria & $\begin{array}{l}\text { Elliker modified by Chamba et al. (1981) pourpre de bromocrésol } \\
\left.\left(\text { Acros Organics }^{2}\right)+\text { thallium acetate (Sigma-Aldrich }{ }^{3}\right)\end{array}$ & $30^{\circ} \mathrm{C}, 72 \mathrm{~h}$ & Surface $(100 \mu \mathrm{L})$ \\
\hline Total staphylococci & Columbia blood agar (Sigma-Aldrich) & $37^{\circ} \mathrm{C}, 48 \mathrm{~h}$ & Surface $(100 \mu \mathrm{L})$ \\
\hline Enterococcus faecalis & Brain-heart infusion agar 15\% (Biokar) & $37^{\circ} \mathrm{C}, 48 \mathrm{~h}$ & Surface $(100 \mu \mathrm{L})$ \\
\hline
\end{tabular}

${ }^{1}$ Biokar, Allonne, France.

${ }^{2}$ Acros Organics, Morris Plains, NJ.

${ }^{3}$ Sigma-Aldrich, Saint-Quentin-Fallavier, France. 
approach adapted from Herrouin et al. (2000) and Vincenzetti et al. (2008). From each milk sample, $20 \mathrm{~mL}$ was taken and skimmed by centrifugation at 3,000 $\times$ $g$ for $30 \mathrm{~min}$ at $32^{\circ} \mathrm{C}$. Whole caseins were precipitated from the skim milk by adjusting the $\mathrm{pH}$ to 4.25 with $\mathrm{HCl}$. After centrifugation, the supernatant samples corresponding to the whey proteins were dialyzed against distilled water at $4^{\circ} \mathrm{C}$ overnight using an Interchim membrane (Montluçon, France) and then freeze-dried and stored at $-18^{\circ} \mathrm{C}$ until analysis. For RP-HPLC (Dionex Ultimate 3000, Thermo Fisher Scientific, Toulouse, France), samples were diluted in Buffer A (0.1 $M$ bis-tris, $\mathrm{pH} 8.0$ containing $8 \mathrm{M}$ urea, $1.3 \%$ trisodium citrate, $0.3 \% \mathrm{DTT}$ ), and 1.13 to $1.25 \mu \mathrm{L}$ of sample was loaded into a $300 \AA$ C8 Zorbax 300SB RP-HPLC column $(5 \mu \mathrm{m}, 4.6 \mathrm{~mm}, 150 \mathrm{~mm}$; Thermo Fisher Scientific). The column was equilibrated with Buffer B (TFA $0.1 \%, \mathrm{H}_{2} \mathrm{O} 95 \%$, acetonitrile $5 \%$ ). Elution was achieved using Buffer B and Buffer C (TFA 0.085\%, $\mathrm{H}_{2} \mathrm{O} 5 \%$, acetonitrile $95 \%$ ) according to the following gradient: 0 to 5 min: $100 \%$ B; 5 to 10 min: $80 \%$ B, $20 \%$ C; 10 to 30 min: $60 \%$ B, $40 \%$ C; 30 to 35 min $100 \%$ B. The flow rate was $1 \mathrm{~mL} / \mathrm{min}$. The proteins eluted from the RP-HPLC column were monitored at $280 \mathrm{~nm}$ by a UV detector (Ultimate $3000 \mathrm{RS}$ diode array detector) included in the HPLC system (Thermo Fisher Scientific). The amount of lysozyme was determined using a calibration curve obtained from a standard chicken egg-white lysozyme prepared in Buffer A and expressed in milligrams per milliliter.

Activity of Lysozyme. Activity of lysozyme was assessed using an EnzCheck Lysozyme Assay Kit (Molecular Probes E-22013; Thermo Fisher Scientific). The LZA levels reflected by the fluorescence intensity were measured by a spectrofluorometer (Tecan SAS, Lyon, France) and quantified via a calibration curve obtained with a standard chicken egg-white lysozyme. The LZA was expressed in units per milliliter.

\section{Thermal Treatments}

To optimize the heat treatment, 10 distinct fresh raw milk samples from La Ferme du Hitton were used. After milking, samples were collected in sterile flasks,

Table 2. Heat treatment conditions

\begin{tabular}{lcc}
\hline Treatment & Temperature $\left({ }^{\circ} \mathrm{C}\right)$ & Time $(\min )$ \\
\hline 1 & 72 & 0.5 \\
2 & 72 & 2 \\
3 & 72 & 3 \\
4 & 72 & 4 \\
5 & 72 & 8 \\
6 & 80 & 10 \\
\hline
\end{tabular}

immediately transported to the laboratory at $4^{\circ} \mathrm{C}$, and heated in a water bath at several combinations of time and temperature (Table 2). Then, samples were rapidly cooled by immersion into cold water. Before and after each heat treatment, LZA was measured. The total bacteria and thermotolerant bacteria E. faecalis were counted after each heat treatment.

\section{In Vivo Experiments}

Animals. Eight-week-old male C57BL/6 mice (weight $23 \pm 0.5$ g; Janvier Labs, Le Genest-Saint-Isle, France) were used. Mice were maintained in pathogenfree animal facilities at a constant temperature $(21 \pm$ $2^{\circ} \mathrm{C}$ ) and a 12-h light/dark cycle. Mice had free access to water and standard rodent pellets (containing 18.6\% CP, $6.2 \%$ crude fat, $5.3 \%$ crude ash, and $3.5 \%$ crude fiber; Harlan Sprague Dawley Inc., Indianapolis, IN). To minimize environmental stress, animals were handled for 1 week before the experiments. Animal care and work protocols, as well as sacrifice procedure, were approved by the local ethical committee, according to EU Directive 2010/63/EU (Agreements \#TOXCOM_0143HE and APAFiS \#4972-2016021814258245).

Water-Avoidance Stress. Briefly, mice were placed on a $3 \times 3$-cm platform fixed in the center of a $40 \times$ 40-cm pool filled with cold water $1 \mathrm{~h}$ per day for $9 \mathrm{~d}$ (Bradesi, 2005). Each WAS sessions was performed between 0800 and $1000 \mathrm{~h}$. Control mice were submitted to a similar procedure using an empty pool (sham stress).

Lipocalin-2 Levels. Lipocalin-2 (LCN-2) is a neutrophil gelatinase-associated lipocalin (NGAL) contained in neutrophil granules, used as a biomarker of intestinal inflammation. To quantify LCN-2, mouse feces were collected and subsequently mixed in PBS for 20 min to obtain a homogeneous fecal suspension (Chassaing et al., 2012). Then the samples were ground using FastPrep (MP Biomedicals, Illkirch, France; 3 times for $15 \mathrm{~s}$ each at $6 \mathrm{~m} / \mathrm{s}$, with 1 -min breaks on ice) and centrifuged for $10 \mathrm{~min}$ at $10,000 \times \mathrm{g}$ at $4^{\circ} \mathrm{C}$. Clear supernatants were collected, and samples were diluted in the kit-recommended reagent diluent $(1.0 \%$ BSA in PBS). We then measured LCN-2 levels using the Duoset murine LCN-2 ELISA kit (R\&D Systems, Minneapolis, MN). The obtained values were normalized by the weight of fecal material.

Gut Permeability. Fluorescein isothiocyanate (FITC) is a small (389 Da) fluorescent molecule present in plasma after an oral administration of FITC. This plasma fluorescence reflects gut permeability status (Inczefi et al., 2014; Edelblum et al., 2017). Mice received $250 \mu \mathrm{L}$ of free FITC $(1 \mathrm{mg} / \mathrm{mL}, \mathrm{F} 7250$; Sigma-Aldrich, Saint-Quentin-Fallavier, France) by oral route. Three hours after FITC administration, a 
blood sample was taken from the facial submandibular vein and centrifuged at $10,000 \times g$ for $10 \mathrm{~min}$. Clear supernatants were collected, and samples were diluted in sterile saline solution ( $\mathrm{NaCl}$ 0.9\%, Sigma-Aldrich). The fluorescence levels present in the plasma were assessed using a TECAN fluorimeter (485 excitation/528 emissions), and the obtained values were normalized by the BW of each mouse. The values were expressed as percentage of difference from the control group.

Experimental Protocol. Male C57BL/6 mice were divided into 6 distinct groups $(\mathrm{n}=10$ per group): 3 control groups and 3 WAS groups. Animals orally received a PBS solution $(0.2 \mathrm{~mL} / \mathrm{d})$, raw DKM $(0.2 \mathrm{~mL} / \mathrm{d})$, or pasteurized DKM (pasteurized for $2 \mathrm{~min}$ at $72^{\circ} \mathrm{C} ; 0.2$ $\mathrm{mL} / \mathrm{d}$, volume adjusted $\pm 0.1 \mathrm{~mL}$, so that each animal received 5,900 U of LZA, as in the raw DKM group), respectively, and the $\mathrm{BW}$ of each mouse was recorded daily. At the end of the WAS or the sham stress procedure, fecal materials were collected to evaluate the gut inflammatory response reflected by fecal LCN-2 levels, and the total gut permeability was assessed as previously described.

\section{Statistical Analysis}

Data were expressed as mean \pm SEM. For statistical analysis, GraphPad Prism 4 (GraphPad, San Diego, CA) was used. For all experimental studies, multiple comparisons between treatments or animal groups were performed using 1-way ANOVA, followed by Bonferroni's multiple comparison test. Statistical significance was accepted at $P<0.05$. To evaluate the correlation between LZA and lysozyme levels, a linear regression was performed to obtain the regression coefficient $\left(R^{2}\right)$.

\section{RESULTS AND DISCUSSION}

\section{Characterization of French Raw Donkey Milk: Microbiological Quality, Lysozyme Content, and Lysozyme Activity}

Samples of French raw DKM showed low total mesophilic microbial counts $\left(3.82 \pm 1.56 \log _{10} \mathrm{cfu} / \mathrm{mL}\right)$. These values are close to the average range $(2.40 \pm$ $1.87 \log _{10} \mathrm{cfu} / \mathrm{mL}$ ) reported in literature (Herrouin et al., 2000; Salimei et al., 2004; Zhang et al., 2008; Pilla et al., 2010; Sarno et al., 2012; Cavallarin et al., 2015; Malissiova et al., 2016; Aspri et al., 2017). Moreover, in the 15 DKM samples tested, no pathogens were detected above the limit prescribed by European and French regulations (EC 853/2004; Regulations of July 13, 2012): absence of Salmonella spp., absence of $L$. monocytogenes, less than $1 \mathrm{cfu} / \mathrm{mL}$ of Escherichia coli, and less than $10 \mathrm{cfu} / \mathrm{mL}$ of coagulase-positive staphy- lococci. The number of thermotolerant coliforms were $2.00 \pm 1.50 \log _{10} \mathrm{cfu} / \mathrm{mL}$, and the mean number of lactic acid bacteria were $2.17 \pm 1.44 \log _{10} \mathrm{cfu} / \mathrm{mL}$, in agreement with previous literature (Chiavari et al., 2005; Zhang et al., 2008; Šarić et al., 2012; Carminati et al., 2014). These data show that French DKM is comparable to Italian, Chinese, or Balkan DKM, with good sanitary quality (low microbial load and absence of pathogenic microorganism); they illustrate good management and hygiene practices in French farms and should encourage French farmers to produce milk for human consumption.

Antimicrobial peptides such as lysozyme and lactoferrin may be responsible for the low bacterial load of DKM and can exert a positive effect on raw milk storage (Zhang et al., 2008). The average lysozyme levels and LZA in the 15 farm samples tested were $2.74 \pm$ $0.88 \mathrm{mg} / \mathrm{mL}$ and $17900 \pm 1636 \mathrm{U} / \mathrm{mL}$, respectively. Although the lysozyme levels mainly depend on the lactation stage and the production season, these concentrations are close to those described in Italian DKM (Vincenzetti et al., 2008; D'Alessandro et al., 2011). The month of lactation affects the concentration of lysozyme in DKM, resulting in a higher concentration of lysozyme during the first 4 mo of lactation and a reduction thereafter (D'Alessandro et al., 2011). Similarly, DKM whey protein concentrations are significantly higher at the beginning of lactation and decrease with time, as observed in humans (Lönnerdal, 2003; D'Alessandro et al., 2011). Concerning LZA, linked to the different published methods of analysis used, the results obtained herein cannot easily be compared with those described in literature. To our knowledge, only a few studies have previously used the EnzCheck (Molecular Probes) assay, and these show similar LZA levels $(15000 \mathrm{U} / \mathrm{mL}$ ) to those obtained in our study (Addo and Ferragut, 2015). Interestingly, LZA levels measured herein for DKM are close to those observed in human breast milk (18,000 U/mL; Sousa et al., 2014).

No correlation between the enzymatic activity and levels of lysozyme was observed in our study (Figure 2 ), which suggests that a large quantity of lysozyme with low enzymatic activity is present in DKM. Due to their role in the development of infants, the amount of bioactive proteins in mammals' milk is considered important (Butte et al., 1984; Lönnerdal, 2003). In newborns, the major function of lysozyme is to strengthen their immature immune system (Cieslak et al., 2017). The biological properties of lysozyme are supported by 2 distinct mechanisms of action on bacterial structures, one of which involves the enzymatic activity of lysozyme, and the second consisting of a non-enzymatic mode of action via cationic properties, which results in a perturbation of the bacterial cyto- 
plasmic membrane (Masschalck et al., 2001). In recent work, we have shown that daily consumption of DKM has anti-inflammatory properties in the gut, in a model of ileitis in mice (Yvon et al., 2018). We observed that this dietary intervention requires significant enzymatic activity of lysozyme as a key condition to obtain a beneficial effect on gastrointestinal mucosa (Yvon et al., 2018). Thermal treatments can reduce the nutritional quality of milk, affecting both the molecular structure and the enzymatic activity of milk proteins such as lysozyme. Based on these observations, we consider LZA to be a biologically active marker in DKM and focused our experiments on developing a heat treatment aimed at safeguarding the antimicrobial enzymatic activity of lysozyme. To define and optimize this heat treatment, we selected 1 DKM from La Ferme du Hitton, which combined good breeding and high quality of life for animals.

\section{Effect of Thermal Treatments on Microbiological Quality and Enzymatic Lysozyme Activity}

Although lysozyme is a temperature-resistant enzyme, heat treatments can significantly reduce its biological activity, with reductions ranging from 21 to 74\% (Wills et al., 1982; Koenig et al., 2005; Czank et al., 2010; Sousa et al., 2014). In our experiments, thermal treatments significantly $(P<0.05)$ affected LZA. (Figure 3A). The most drastic decreases were observed in treatments of $8 \mathrm{~min}$ at $72^{\circ} \mathrm{C}$ and $10 \mathrm{~min}$ at $80^{\circ} \mathrm{C}$, which showed reductions of $27.15 \pm 5.32 \%$ and 60.79 $\pm 11.65 \%$ of LZA, respectively, compared with LZA measured in raw DKM (Figure 3A). Heat treatment of DKM for $4 \mathrm{~min}$ at $72^{\circ} \mathrm{C}$ induced a reduction of 13.77

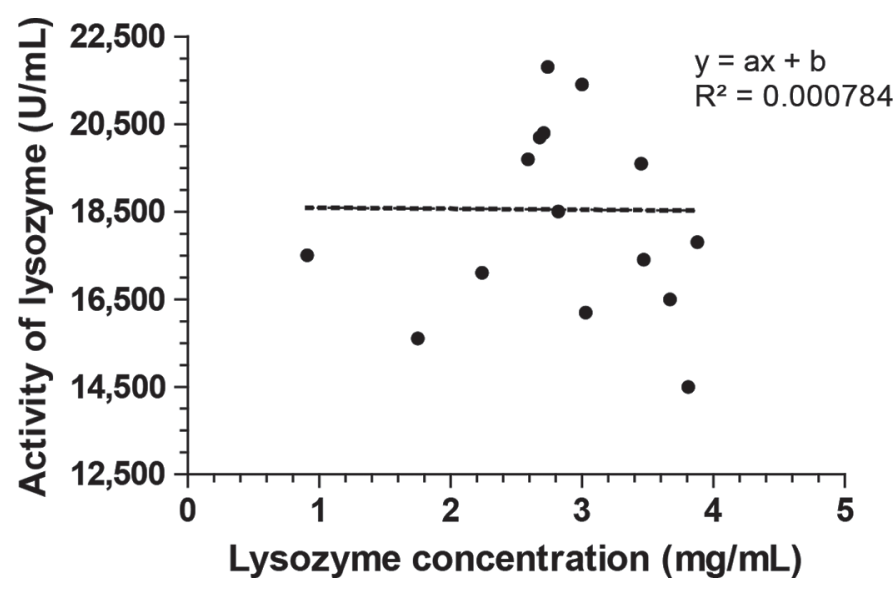

Figure 2. Correlation between enzymatic activity $(\mathrm{U} / \mathrm{mL})$ and concentration of lysozyme $(\mathrm{mg} / \mathrm{mL})$ in donkey milk from 15 French farms. Linear regression: $\mathrm{R}^{2}=0.000784$, indicating that the equation of the regression line determines $0.0784 \%$ of the distribution of points. $\pm 2.70 \%$ of LZA compared with raw DKM. Pasteurization of DKM for $30 \mathrm{~s}, 2 \mathrm{~min}$, or $3 \mathrm{~min}$ at $72^{\circ} \mathrm{C}$ had no significant effect $(P<0.05)$ on LZA compared with LZA measured in raw DKM (Figure 3A). Previous studies have showed that pasteurization in the same range of treatment times and temperatures had little effect on the content of other interesting compounds in DKM, such as immunoglobulins (IgA, IgG; Aspri et al., 2017) and vitamins (MacDonald et al., 2011) compared with raw DKM.

In the raw DKM tested, the total bacterial load was $3.90 \log _{10} \mathrm{cfu} / \mathrm{mL}$. Thermal treatments safeguarding LZA - that is, $30 \mathrm{~s}$ at $72^{\circ} \mathrm{C} ; 2 \mathrm{~min}$ at $72^{\circ} \mathrm{C}$; or $3 \mathrm{~min}$ at $72^{\circ} \mathrm{C}$ - greatly decreased the total bacterial count (TBC), with a reduction of $2 \log _{10} \mathrm{cfu} / \mathrm{mL}$, representing less than $100 \mathrm{cfu} / \mathrm{mL}$ in heated DKM (Figure 3B). Because our selected DKM contained a low load of total bacterial and no pathogen strains, to mimic poorer conditions of breeding and milking, 2 types of DKM were produced: DKM enriched with endogenous bacteria (Figure 3B) and DKM artificially contaminated with the thermotolerant E. faecalis (Figure 3B). Treatment for $30 \mathrm{~s}$ at $72^{\circ} \mathrm{C}$ reduced $\mathrm{TBC}$ by more than $4 \log _{10} \mathrm{cfu} / \mathrm{mL}$ (from 6.85 to $2.53 \log _{10} \mathrm{cfu} / \mathrm{mL}$ ) in the bacteria-enriched DKM but had little effect (reduction of less than $2 \mathrm{cfu} / \mathrm{mL}$ of $E$. faecalis) on the artificially contaminated milk (from 7.56 to $6.11 \log _{10} \mathrm{cfu} / \mathrm{mL}$ ). The $2 \mathrm{~min}, 72^{\circ} \mathrm{C}$, treatment permitted a $2 \log _{10} \mathrm{cfu} / \mathrm{mL}$ reduction of TBC in enriched DKM and a $4.2 \log _{10} \mathrm{cfu} /$ $\mathrm{mL}$ reduction of $E$. faecalis in artificially contaminated DKM. Considering the low bacterial load in DKM (Table 3), we selected the 2 -min treatment at $72^{\circ} \mathrm{C}$, because it permitted reduction in both $\mathrm{TBC}$ and thermotolerant E. faecalis, while preserving LZA in DKM.

\section{Aging Tests for Safety and Freshness Guarantees of Selected Heat-Treated DKM}

According to the safety and hygiene criteria defined by the regulation of food microbiology no. 1441/2007 and 852/2004 (European Commission, 2004, 2007), samples of DKM previously submitted to heat treatment $\left(2 \mathrm{~min}\right.$ at $\left.72^{\circ} \mathrm{C}\right)$ were analyzed at different time points. At $20 \mathrm{~d}$ post-treatment, total mesophilic bacteria were less than 10,000 cfu/mL. After 7, 10, 13, 15, and $20 \mathrm{~d}$ post-treatment, no L. monocytogenes and no salmonella were detected in DKM. For suspected enterobacteria, Escherichia coli-positive $\beta$-glucuronidase, and coagulase-positive staphylococci, fewer than 10 $\mathrm{cfu} / \mathrm{mL}$ were counted, reflecting applicable criteria for DKM intended for human consumption. Indeed, an adequate heat treatment of milk must (1) make milk and milk products safe for human consumption by reducing the number of viable bacteria that may 
A

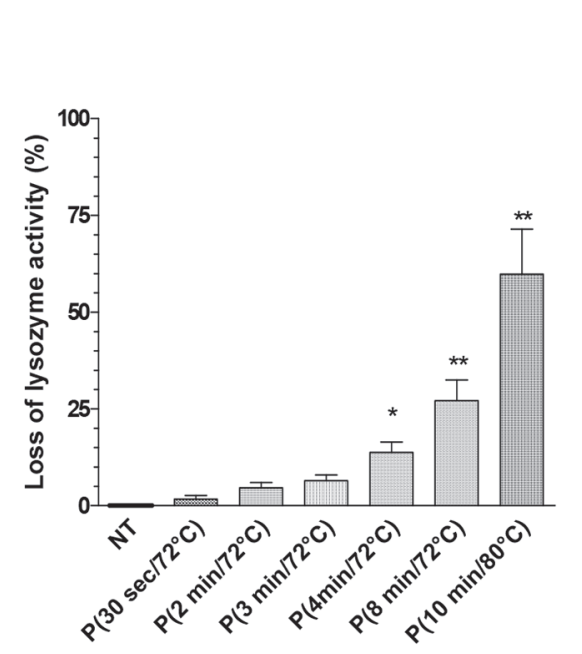

B

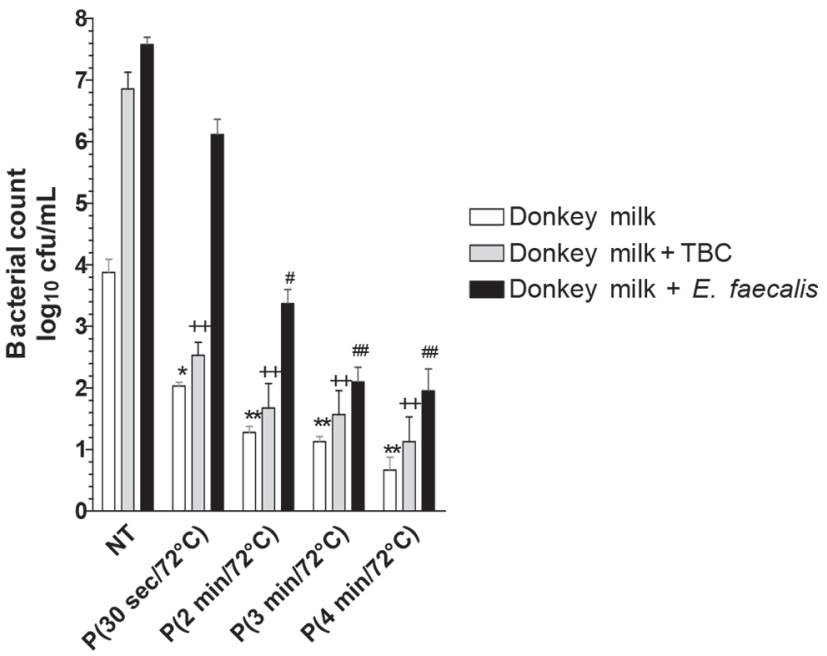

Figure 3. (A) Effects of thermal treatments (pasteurization, P) on enzymatic lysozyme activity in bacteria-enriched raw donkey milk (DKM): ${ }^{*} P<0.05,{ }^{* *} P<0.01$, compared with non-heat treated (NT) raw DKM. (B) Effects of thermal treatments on total bacterial count (TBC) in DKM: ${ }^{*} P<0.05,{ }^{* *} P<0.01$ compared with NT (donkey milk, unshaded bars) $++P<0.01$ compared with bacteria-enriched DKM (donkey milk + TBC, gray-shaded bars); and \#P<0.05, \#\#P<0.01 compared with DKM contaminated with Enterococcus faecalis (donkey milk + E. faecalis, black bars). Error bars represent standard error of the mean.

be harmful to health and (2) improve the shelf life of milk by reducing the numbers of spoilage bacteria (LeJeune and Rajala-Schultz, 2009). In our study, the heat treatment applied $\left(2\right.$ min at $\left.72^{\circ} \mathrm{C}\right)$ extends the previous shelf life period described, $3 \mathrm{~d}$ at $4^{\circ} \mathrm{C}$ for raw DKM (Zhang et al., 2008), to $20 \mathrm{~d}$ at $4^{\circ} \mathrm{C}$ for treated DKM. Moreover, to further increase shelf life, milk can be frozen after pasteurization. Indeed, pasteurization and freezing after pasteurization are usual procedures carried out for human milk banks. Human breast milk frozen after pasteurization does not present any significant changes of the protein fraction (García-Lara et al., 2013). Pasteurization before freezing also denaturizes enzymes involved in producing bitter flavor and rancidity of milk during storage (Lemieux and Simard, 1991) and so should improve the taste and flavor of DKM.

Table 3. Microbiological characteristics and lysozyme content and activity of French raw donkey milk; values \pm standard deviation

\begin{tabular}{lc}
\hline Item & Value \\
\hline Bacterial count $\left(\log _{10} \mathrm{cfu} / \mathrm{mL}\right)$ & \\
Total mesophilic bacteria & $3.82 \pm 1.56$ \\
Lactic acid bacteria & $2.17 \pm 1.44$ \\
Thermotolerant coliforms & $2.00 \pm 1.50$ \\
Staphylococci (coagulase positive) & $<10 \mathrm{cfu} / \mathrm{mL}$ \\
Escherichia coli & $<1 \mathrm{cfu} / \mathrm{mL}$ \\
Salmonella spp. in $10 \mathrm{~g}$ & 0 \\
Listeria monocytogenes in $10 \mathrm{~g}$ & 0 \\
Lysozyme & $2.74 \pm 0.88$ \\
Level $(\mathrm{mg} / \mathrm{mL})$ & $17,900 \pm 1,636$ \\
Activity $(\mathrm{U} / \mathrm{mL})$ & \\
\hline
\end{tabular}

\section{Evaluation of Beneficial Effects of Raw vs. Heat-Treated DKM}

In physiological conditions, oral administration of raw or heat-treated DKM $\left(2\right.$ min at $\left.72^{\circ} \mathrm{C}\right)$, containing similar LZA (5900 U), at $0.2 \mathrm{~mL} / \mathrm{d}$ did not change basal total gut permeability in unstressed mice compared with unstressed control animals who received PBS [4.19 \pm 0.68 and $4.04 \pm 0.45$, vs. $2.70 \pm 0.28 \mathrm{ng}$ of FITC per $\mathrm{mL}$ of plasma, respectively (Figure $4 \mathrm{~A}$ ); the obtained values were normalized by the BW (g) of each mouse]. In the same way, both treatments (raw or heat-treated DKM) had no effect on levels of the fecal inflammatory marker LCN-2 compared with control mice (23.57 \pm 6.48 and $13.80 \pm 3.09$, vs. $15.75 \pm 2.91 \mathrm{ng} / \mathrm{g}$ of feces, respectively; Figure 3B). In contrast, chronic psychological stress (WAS) induced a significant increase $(P<$ 0.001) of total gut permeability to free FITC molecules $(10.85 \pm 1.06 \mathrm{ng} / \mathrm{mL})$. This increased gut permeability is associated with a significant increase $(P<0.05)$ of LCN-2 levels $(+84.48 \pm 36.51 \mathrm{ng} / \mathrm{g}$ of feces $)$ assessed in WAS mice. These effects of increased gut permeability and micro-inflammation were significantly counteracted $(P<0.01)$ by oral treatment with both raw and heat-treated DKM. To reinforce these data, further experiments using several milk samples from different farms and countries should be performed, to consolidate their effects on gut function after this specific heat treatment. As described in the introduction, DKM is a complex matrix containing several mediators such as 
A

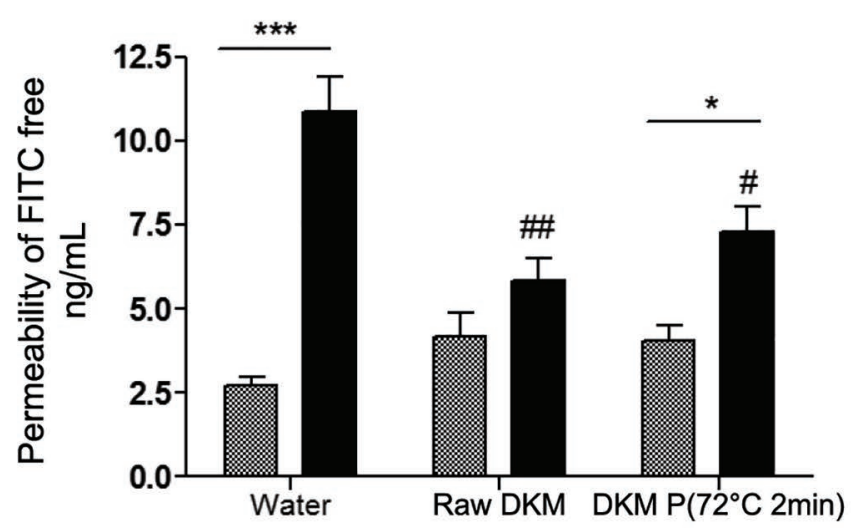

B

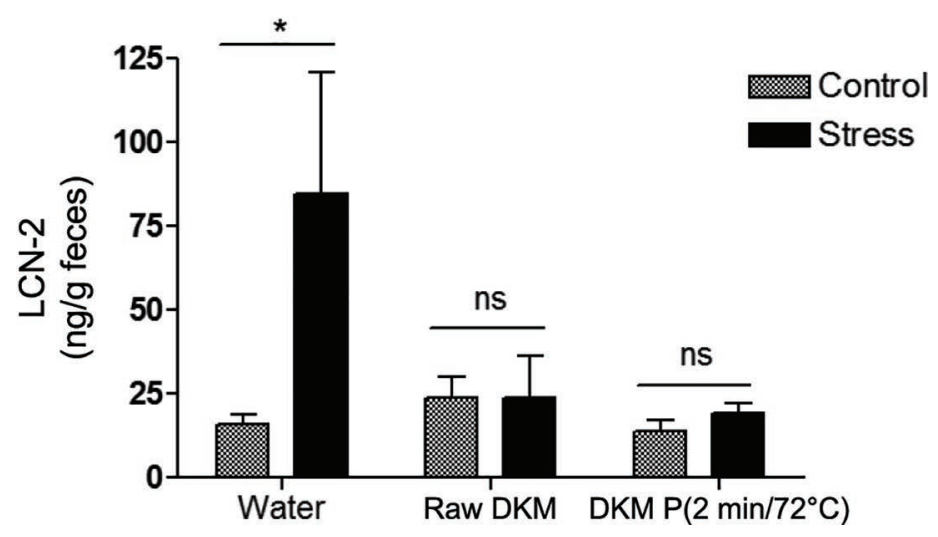

Figure 4. Effect of consumption of water or raw or pasteurized donkey milk (DKM) on gut permeability of fluorescein isothiocyanate (FITC;

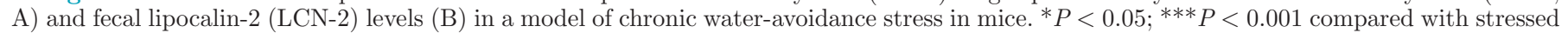
mice. \#P $<0.05$; \#\# $P<0.01$ compared with consumption of water among stressed mice. Gray shaded bars $=$ unstressed mice (control); black bars $=$ mice subjected to water-avoidance stress. $\mathrm{P}=$ pasteurized. Error bars represent standard error of the mean.

interferon $\gamma(\mathrm{IFN} \gamma)$, lysozyme, lactoferrin, and TGF- $\beta$. Therefore, in our study, we cannot exclude the possibility that heat-treated DKM could exert beneficial effects on gut functions not only via lysozyme activity but also via other mediators that might resist the treatment process.

Increased intestinal epithelial permeability has been implicated as a prerequisite in the pathophysiology of IBS (Spiller et al., 2000) and has also been found in animal models of chronic stress (Söderholm et al., 2002; Barreau et al., 2004). Additionally, IBS is associated with mucosal immune stimulation, a micro-inflammatory state characterized by increased density of immunocytes and mast cells in the gut mucosa (Guilarte et al., 2007). Altered mucosal barrier permeability facilitates the entry of toxins and bacteria and is considered to be responsible for mucosal micro-inflammation (Hyland et al., 2014). Furthermore, in IBS, increased gut permeability is positively correlated with visceral pain (Zhou et al., 2009), and in rodents stress-induced gut hyperpermeability is also responsible for visceral hypersensitivity (Ait-Belgnaoui et al., 2005). In this context, alteration of intestinal permeability constitutes a clear target in pathophysiological treatment for IBS today.

\section{CONCLUSIONS}

Based on the beneficial effect of DKM, heat treated according to our defined procedure, on WAS-induced intestinal damage and the observations previously published in preclinical stress models and in human IBS patients, we propose oral consumption of DKM as an intervention against intestinal barrier dysfunction due to psychological stress. However, other studies are needed to assess the efficacy and safety of DKM in the management of IBS symptoms. We first suggest testing the beneficial effects of DKM on a model of stress-induced visceral hypersensitivity.

\section{ACKNOWLEDGMENTS}

The authors thank Christel Couderc, Mireille Gaucher, and Henri Tonglet (Institut National PolytechniquePurpan, Toulouse, France) for their technical assistance. The authors also thank the Institut National Âne et Mulet (INAM) and the Ecole d'Ingénieurs de Purpan for their financial support. Thanks to Marlene Fraysse (Valence d'Agen, France) and Jasper Kamphuis (Institut National de la Recherche Agronomique Toxalim, Toulouse, France) for their proofreading.

\section{REFERENCES}

Addo, C. N. A., and V. Ferragut. 2015. Evaluating the ultra-high pressure homogenization (UHPH) and pasteurization effects on the quality and shelf life of donkey milk. Int. J. Food Stud. 4. https: //www.iseki-food-ejournal.com/ojs/index.php/e-journal/article/ view/271

Ait-Belgnaoui, A., S. Bradesi, J. Fioramonti, V. Theodorou, and L. Bueno. 2005. Acute stress-induced hypersensitivity to colonic distension depends upon increase in paracellular permeability: role of myosin light chain kinase. Pain 113:141-147. https://doi.org/10 .1016/j.pain.2004.10.002.

Aspri, M., D. Bozoudi, D. Tsaltas, C. Hill, and P. Papademas. 2016. Raw donkey milk as a source of Enterococcus diversity: Assessment of their technological properties and safety characteristics. Food Control. https://doi.org/10.1016/j.foodcont.2016.05.022.

Aspri, M., N. Economou, and P. Papademas. 2017. Donkey milk: An overview on functionality, technology, and future prospects. Food Rev. Int. 33:316-333. https://doi.org/10.1080/87559129.2016 .1175014 .

Barreau, F., C. Cartier, L. Ferrier, J. Fioramonti, and L. Bueno. 2004. Nerve growth factor mediates alterations of colonic sensitivity and 
mucosal barrier induced by neonatal stress in rats. Gastroenterology 127:524-534. https://doi.org/10.1053/j.gastro.2004.05.019.

Bradesi, S. 2005. Repeated exposure to water avoidance stress in rats: A new model for sustained visceral hyperalgesia. Am. J. Physiol. Gastrointest. Liver Physiol. 289:G42-G53. https://doi.org/10 .1152 /ajpgi.00500.2004.

Brumini, D., A. Criscione, S. Bordonaro, G. E. Vegarud, and D. Marletta. 2015. Whey proteins and their antimicrobial properties in donkey milk: A brief review. Dairy Sci. Technol. https://doi.org/ 10.1007/s13594-015-0246-1.

Butte, N. F., C. Garza, E. O. Smith, and B. L. Nichols. 1984. Human milk intake and growth in exclusively breast-fed infants. J. Pediatr. 104:187-195. https://doi.org/10.1016/S0022-3476(84)80990-7.

Carminati, D., F. Tidona, M. E. Fornasari, L. Rossetti, A. Meucci, and G. Giraffa. 2014. Biotyping of cultivable lactic acid bacteria isolated from donkey milk. Lett. Appl. Microbiol. 59:299-305. https: //doi.org/10.1111/lam.12275.

Carroccio, A., F. Cavataio, G. Montalto, D. D'Amico, L. Alabrese, and G. Iacono. 2000. Intolerance to hydrolysed cow's milk proteins in infants: Clinical characteristics and dietary treatment. Clin. Exp. Allergy. 30:1597-1603.

Cavallarin, L., M. Giribaldi, M. D. L. D. Soto-Del Rio, E. Valle, G. Barbarino, M. S. Gennero, and T. Civera. 2015. A survey on the milk chemical and microbiological quality in dairy donkey farms located in NorthWestern Italy. Food Control 50:230-235. https:// doi.org/10.1016/j.foodcont.2014.08.019.

Chamba, J. F., G. Bonnaz, and P. Bourg. 1981. Comparaisons de diverses méthodes de dénombrement de la flore acidifiante du lait cru. Lait 61:555-567. https://doi.org/10.1051/lait:1981609-61035.

Chassaing, B., G. Srinivasan, M. A. Delgado, A. N. Young, A. T. Gewirtz, and M. Vijay-Kumar. 2012. Fecal lipocalin 2, a sensitive and broadly dynamic non-invasive biomarker for intestinal inflammation. PLoS One 7:e44328. https://doi.org/10.1371/journal.pone .0044328 .

Chiavari, C., F. Coloretti, M. Nanni, E. Sorrentino, and L. Grazia. 2005. Use of donkey's milk for a fermented beverage with lactobacilli. Lait 85:481-490. https://doi.org/10.1051/lait:2005031.

Cieslak, J., L. Wodas, A. Borowska, J. Sadoch, P. Pawlak, K. Puppel, B. Kuczynska, and M. Mackowski. 2017. Variability of lysozyme and lactoferrin bioactive protein concentrations in equine milk in relation to LYZ and LTF gene polymorphisms and expression. J. Sci. Food Agric. 97:2174-2181. https://doi.org/10.1002/jsfa.8026.

Cosentino, C., C. Labella, H. S. Elshafie, I. Camele, M. Musto, R. Paolino, C. D'Adamo, and P. Freschi. 2016. Effects of different heat treatments on lysozyme quantity and antimicrobial activity of jenny milk. J. Dairy Sci. 99:5173-5179. https://doi.org/10.3168/ jds.2015-10702.

Cosentino, C., R. Paolino, M. Musto, and P. Freschi. 2015a. Innovative use of jenny milk from sustainable rearing. Pages 113-132 in The Sustainability of Agro-Food and Natural Resource Systems in the Mediterranean Basin. A. Vastola, ed. Springer International Publishing, New York, NY.

Cosentino, C., R. Paolino, V. Valentini, M. Musto, A. Ricciardi, F. Adduci, C. D'Adamo, G. Pecora, and P. Freschi. 2015b. Effect of jenny milk addition on the inhibition of late blowing in semihard cheese. J. Dairy Sci. 98:5133-5142. https://doi.org/10.3168/jds .2015-9458.

Czank, C., K. Simmer, and P. E. Hartmann. 2010. Simultaneous pasteurization and homogenization of human milk by combining heat and ultrasound: Effect on milk quality. J. Dairy Res. 77:183-189. https://doi.org/10.1017/S0022029909990483.

D'Alessandro, A. G., G. Martemucci, E. Jirillo, and V. D. Leo. 2011. Major whey proteins in donkey's milk: Effect of season and lactation stage. Implications for potential dietary interventions in human diseases. Immunopharmacol. Immunotoxicol. 33:259-265. https://doi.org/10.3109/08923973.2010.499365.

Edelblum, K. L., G. Sharon, G. Singh, M. A. Odenwald, A. Sailer, S. Cao, S. Ravens, I. Thomsen, K. El Bissati, R. McLeod, C. Dong, S. Gurbuxani, I. Prinz, S. K. Mazmanian, and J. R. Turner. 2017. The microbiome activates CD4 T-cell-mediated immunity to compensate for increased intestinal permeability. Cell. Mol. Gastro- enterol. Hepatol. 4:285-297. https://doi.org/10.1016/j.jcmgh.2017 .06 .001 .

European Commission. 2004. Regulation (EC) No 852/2004 of the European Parliament and of the Council of 29 April 2004 on the hygiene of foodstuffs. https://www.fsai.ie/uploadedFiles/Consol _Reg852_2004.pdf.

European Commission. 2007. Commission regulation (EC) No $1441 / 2007$ of 5 December 2007 amending Regulation (EC) No 2073/2005 on microbiological criteria for foodstuffs. https://eur -lex.europa.eu/LexUriServ/LexUriServ.do?uri=OJ:L:2007:322: 0012:0029:EN:PDF.

Ferrier, L., F. Bérard, L. Debrauwer, C. Chabo, P. Langella, L. Buéno, and J. Fioramonti. 2006. Impairment of the intestinal barrier by ethanol involves enteric microflora and mast cell activation in rodents. Am. J. Pathol. 168:1148-1154. https://doi.org/10.2353/ ajpath.2006.050617.

García-Lara, N. R., D. E. Vieco, J. De la Cruz-Bértolo, D. Lora-Pablos, N. U. Velasco, and C. R. Pallás-Alonso. 2013. Effect of Holder pasteurization and frozen storage on macronutrients and energy content of breast milk. J. Pediatr. Gastroenterol. Nutr. 57:377382. https://doi.org/10.1097/MPG.0b013e31829d4f82.

Gottlieb, M.G.V., V.E. Closs, V.M. Junges, and C.H.A. Schwanke. 2017. Impact of human aging and modern lifestyle on microbiota. Crit. Rev. Food Sci. Nutr. 58:1557-1564. https://doi.org/10.1080/ 10408398.2016.1269054.

Guilarte, M., J. Santos, I. de Torres, C. Alonso, M. Vicario, L. Ramos, C. Martinez, F. Casellas, E. Saperas, and J. R. Malagelada. 2007. Diarrhoea-predominant IBS patients show mast cell activation and hyperplasia in the jejunum. Gut 56:203-209. https://doi.org/10 $.1136 /$ gut.2006.100594

Guo, H. Y., K. Pang, X. Y. Zhang, L. Zhao, S. W. Chen, M. L. Dong, and F. Z. Ren. 2007. Composition, physiochemical properties, nitrogen fraction distribution, and amino acid profile of donkey milk. J. Dairy Sci. 90:1635-1643. https://doi.org/10.3168/jds.2006-600.

Hébert, L., P. Courtin, R. Torelli, M. Sanguinetti, M.-P. ChapotChartier, Y. Auffray, and A. Benachour. 2007. Enterococcus faecalis constitutes an unusual bacterial model in lysozyme resistance. Infect. Immun. 75:5390-5398. https://doi.org/10.1128/IAI.00571 -07 .

Herrouin, M., D. Mollé, J. Fauquant, F. Ballestra, J.-L. Maubois, and J. Léonil. 2000. New genetic variants identified in donkey's milk whey proteins. J. Protein Chem. 19:105-115.

Hyland, N. P., E. M. Quigley, and E. Brint. 2014. Microbiota-host interactions in irritable bowel syndrome: Epithelial barrier, immune regulation and brain-gut interactions. World J. Gastroenterol. 20:8859. https://doi.org/10.3748/wjg.v20.i27.8859.

Inczefi, O., H. Eutamene, M. Leveque, C. Bétoulières, R. Róka, T. Wittmann, J. R. Turner, V. Theodorou, and L. Ferrier. 2014. Congenitally elevated gut permeability is linked to basal visceral hyposensitivity but stress-induced visceral hypersensitivity in CAMLCK mice. Gastroenterology 146:S-21. (Abstr.) https://doi.org/ 10.1016/S0016-5085(14)60076-7.

Jirillo, F., E. Jirillo, and T. Magrone. 2010. Donkey's and goat's milk consumption and benefits to human health with special reference to the inflammatory status. Curr. Pharm. Des. 16:859-863.

Kayser, F. H. 2003. Safety aspects of enterococci from the medical point of view. Int. J. Food Microbiol. 88:255-262. https://doi.org/ 10.1016/S0168-1605(03)00188-0.

Kearns, A. M., R. Freeman, and N. F. Lightfoot. 1995. Nosocomial enterococci: Resistance to heat and sodium hypochlorite. J. Hosp. Infect. 30:193-199. https://doi.org/10.1016/S0195-6701(95)90314-3.

Koenig, Á., E. M. de A. Diniz, S. F. C. Barbosa, and F. A. C. Vaz. 2005. Immunologic factors in human milk: The effects of gestational age and pasteurization. J. Hum. Lact. 21:439-443. https:// doi.org/10.1177/0890334405280652.

Labella, C., F. Lelario, A. Bufo, M. Musto, P. Freschi, and C. Cosentino. 2016. Optimization and validation of a chromatographic method for quantification of the lysozyme in jenny milk. J. Food Nutr. 55:263-269.

Larauche, M., A. Mulak, and Y. Taché. 2011. Stress-related alterations of visceral sensation: Animal models for irritable bowel syndrome 
study. J. Neurogastroenterol. Motil. 17:213-234. https://doi.org/ 10.5056/jnm.2011.17.3.213.

LeJeune, J. T.,, and P. J. Rajala-Schultz. 2009. Unpasteurized milk: A continued public health threat. Clin. Infect. Dis. 48:93-100. https: //doi.org/10.1086/595007.

Lemieux, L., and R. E. Simard. 1991. Bitter flavour in dairy products. I. A review of the factors likely to influence its development, mainly in cheese manufacture. Lait 71:599-636.

Lerebours, E., C. Gower-Rousseau, V. Merle, F. Brazier, S. Debeugny, R. Marti, J. L. Salomez, M. F. Hellot, J. L. Dupas, J. F. Colombel, A. Cortot, and J. Benichou. 2007. Stressful life events as a risk factor for inflammatory bowel disease onset: A population-based case-control study. Am. J. Gastroenterol. 102:122-131. https://doi .org/10.1111/j.1572-0241.2006.00931.x.

Lönnerdal, B. 2003. Nutritional and physiologic significance of human milk proteins. Am. J. Clin. Nutr. 77:1537S-1543S.

Ma, N., P. Guo, J. Zhang, T. He, S. W. Kim, G. Zhang, and X. Ma. 2018. Nutrients mediate intestinal bacteria-mucosal immune crosstalk. Front. Immunol. 9. https://doi.org/10.3389/fimmu.2018 .00005 .

MacDonald, L. E., J. Brett, D. Kelton, S. E. Majowicz, K. Snedeker, and J. M. Sargeant. 2011. A systematic review and meta-analysis of the effects of pasteurization on milk vitamins, and evidence for raw milk consumption and other health-related outcomes. J. Food Prot. 74:1814-1832.

Malissiova, E., G. Arsenos, P. Papademas, D. Fletouris, A. Manouras, M. Aspri, A. Nikolopoulou, A. Giannopoulou, and I. S. Arvanitoyannis. 2016. Assessment of donkey milk chemical, microbiological and sensory attributes in Greece and Cyprus. Int. J. Dairy Technol. 69:143-146. https://doi.org/10.1111/1471-0307.12245.

Mao, X., J. Gu, Y. Sun, S. Xu, X. Zhang, H. Yang, and F. Ren. 2009. Anti-proliferative and anti-tumour effect of active components in donkey milk on A549 human lung cancer cells. Int. Dairy J. 19:703-708. https://doi.org/10.1016/j.idairyj.2009.05.007.

Marco, M. L., D. Heeney, S. Binda, C. J. Cifelli, P. D. Cotter, B. Foligné, M. Gänzle, R. Kort, G. Pasin, A. Pihlanto, E. J. Smid, and R. Hutkins. 2017. Health benefits of fermented foods: Microbiota and beyond. Curr. Opin. Biotechnol. 44:94-102. https://doi.org/ 10.1016/j.copbio.2016.11.010.

Masschalck, B., R. V. Houdt, E. G. R. V. Haver, and C. W. Michiels. 2001. Inactivation of gram-negative bacteria by lysozyme, denatured lysozyme, and lysozyme-derived peptides under high hydrostatic pressure. Appl. Environ. Microbiol. 67:339-344. https://doi .org/10.1128/AEM.67.1.339-344.2001.

Moloney, R. D., A. C. Johnson, S. M. O'Mahony, T. G. Dinan, B. Greenwood-Van Meerveld, and J. F. Cryan. 2016. Stress and the microbiota-gut-brain axis in visceral pain: Relevance to irritable bowel syndrome. CNS Neurosci. Ther. 22:102-117. https://doi .org/10.1111/cns.12490.

Pilla, R., V. Daprà, A. Zecconi, and R. Piccinini. 2010. Hygienic and health characteristics of donkey milk during a followup study. J. Dairy Res. 77:392-397. https://doi.org/10.1017/ S0022029910000221.

Salimei, E., F. Fantuz, R. Coppola, B. Chiofalo, P. Polidori, and G. Varisco. 2004. Composition and characteristics of ass's milk. Anim. Res. 53:67-78. https://doi.org/10.1051/animres:2003049.

Šarić, L. Ć., B. M. Šarić, A. I. Mandić, A. M. Torbica, J. M. Tomić, D. D. Cvetković, and Đ. G. Okanović. 2012. Antibacterial properties of domestic Balkan donkeys' milk. Int. Dairy J. 25:142-146. https: //doi.org/10.1016/j.idairyj.2012.03.007.

Sarno, E., A. M. L. Santoro, R. Di Palo, and N. Costanzo. 2012. Microbiological quality of raw donkey milk from Campania Region. Ital. J. Anim. Sci. 11:e49. https://doi.org/10.4081/ijas.2012.e49.
Söderholm, J. D., P.-C. Yang, P. Ceponis, A. Vohra, R. Riddell, P. M. Sherman, and M. H. Perdue. 2002. Chronic stress induces mast cell-dependent bacterial adherence and initiates mucosal inflammation in rat intestine. Gastroenterology 123:1099-1108.

Sousa, S. G., I. Delgadillo, and J. A. Saraiva. 2014. Effect of thermal pasteurisation and high-pressure processing on immunoglobulin content and lysozyme and lactoperoxidase activity in human colostrum. Food Chem. 151:79-85. https://doi.org/10.1016/j.foodchem .2013.11.024.

Spiller, R. C., D. Jenkins, J. P. Thornley, J. M. Hebden, T. Wright, M. Skinner, and K. R. Neal. 2000. Increased rectal mucosal enteroendocrine cells, T lymphocytes, and increased gut permeability following acute Campylobacter enteritis and in post-dysenteric irritable bowel syndrome. Gut 47:804-811. https://doi.org/10.1136/ gut.47.6.804.

Tafaro, A., T. Magrone, F. Jirillo, G. Martemucci, A. G. D'Alessandro, L. Amati, and E. Jirillo. 2007. Immunological properties of donkey's milk: its potential use in the prevention of atherosclerosis. Curr. Pharm. Des. 13:3711-3717.

van der Voorn, B., M. de Waard, L. R. Dijkstra, A. C. Heijboer, J. Rotteveel, J. B. van Goudoever, and M. J. J. Finken. 2017. Stability of Cortisol and cortisone in human breast milk during Holder pasteurization. J. Pediatr. Gastroenterol. Nutr. https://doi.org/10 .1097/MPG.0000000000001678.

Verraes, C., W. Claeys, S. Cardoen, G. Daube, L. De Zutter, H. Imberechts, K. Dierick, and L. Herman. 2014. A review of the microbiological hazards of raw milk from animal species other than cows. Int. Dairy J. 39:121-130. https://doi.org/10.1016/j.idairyj .2014.05.010.

Vincenzetti, S., P. Polidori, P. Mariani, N. Cammertoni, F. Fantuz, and A. Vita. 2008. Donkey's milk protein fractions characterization. Food Chem. 106:640-649. https://doi.org/10.1016/j .foodchem.2007.06.026.

Vivinus-Nébot, M., G. Frin-Mathy, H. Bzioueche, R. Dainese, G. Bernard, R. Anty, J. Filippi, M. C. Saint-Paul, M. K. Tulic, V. Verhasselt, X. Hébuterne, and T. Piche. 2013. Functional bowel symptoms in quiescent inflammatory bowel diseases: role of epithelial barrier disruption and low-grade inflammation. Gut 63:744-752. https://doi.org/10.1136/gutjnl-2012-304066.

Watanabe, Y., S. Arase, N. Nagaoka, M. Kawai, and S. Matsumoto. 2016. Chronic psychological stress disrupted the composition of the murine colonic microbiota and accelerated a murine model of inflammatory bowel disease. PLoS One 11:e0150559. https://doi .org/10.1371/journal.pone.0150559.

Wills, M. E., V. E. M. Han, D. A. Harris, and J. D. Baum. 1982. Short-time low-temperature pasteurisation of human milk. Early Hum. Dev. 7:71-80. https://doi.org/10.1016/0378-3782(82)90009 $-3$.

Yvon, S., M. Olier, M. Leveque, G. Jard, H. Tormo, D. A. HaimoudLekhal, M. Peter, and H. Eutamène. 2018. Donkey milk consumption exerts anti-inflammatory properties by normalizing antimicrobial peptides levels in Paneth's cells in a model of ileitis in mice. Eur. J. Nutr. https://doi.org/10.1007/s00394-016-1304-z.

Zhang, X.-Y., L. Zhao, L. Jiang, M.-L. Dong, and F.-Z. Ren. 2008. The antimicrobial activity of donkey milk and its microflora changes during storage. Food Control 19:1191-1195. https://doi.org/10 $.1016 /$ j.foodcont.2008.01.005.

Zhou, Q., B. Zhang, and G. Nicholas Verne. 2009. Intestinal membrane permeability and hypersensitivity in the irritable bowel syndrome. Pain 146:41-46. https://doi.org/10.1016/j.pain.2009.06.017. 